\title{
Waria dalam Perspekif Masyarakat di Desa Timu Kecamatan Bolo Kabupaten Bima (Ditinjau dari Aspek Fenomenologis)
}

\author{
A. Gafar Hidayat ${ }^{1}$, Tati Haryati ${ }^{1}$, Rosdiana ${ }^{1}$ \\ ${ }^{1}$ STKIP Taman Siswa Bima \\ "gafarhidayat@gmail.com
}

Artikel Info

$\underline{\text { Tanggal Publikasi }}$

$2021-06-30$

\section{$\underline{\text { Kata Kunci }}$}

Waria

Masyarakat

\section{Abstrak}

Pola hidup waria dinilai tidak lazim dan menyimpang, bagi masyarakat pada umumnya, namun bagi sebahagian kecil individu beranggapan pola hidup tersebut, suatu hal yang unik. Keberadaan waria dianggap sebagai pola kehidupan yang buruk dan membawa dampak negatif pada perkembangan generasi. Disisi lain terdapat sebahagian kecil individu yang menghargai dengan keberadaannya dan dianggap sebagai keberagaman biasa dalam dinamika kehidupan bermasyarakat.Tujuan penelitian ini yaitu; 1) mendeskripsikan berbagai tanggapan masyarakat terhadap pola hidup waria; 2) mengidentifikasi berbagai upaya yang dilakukan oleh waria agar diterima dilingkungan masyarakat. Penelitian ini menggunakan metode deskriptif kualitatif, sumber data terdiri dari sumber data sekunder dan sumber data primer. Dan teknik pengumpulan data dilakukan melalui observasi, wawancara mendalam, juga dokumentasi. Uraian yang tertuang didalamnya berdasarkan fenomena riil di lapangan yang di temui oleh peneliti. Berdasarkan hasil penelitian yang dilakukan bahwa; 1) tanggapan masyarakat terhadap pola hidup waria yaitu; a) waria dinilai oleh masyarakat pada umumnya sebagai prilaku menyimpang, melanggar kodrat tuhan dan norma agama; 2) menimbulkan keresahan dan kekhawatiran para orangtua, karena hawatir anak-anaknya terjerumus dalam pola pergaulan waria; c) sebahagian kecil masyarakat menggap bahwa waria sebagai dinamika kehidupan bermasyarakat yang biasa-biasa saja.; 2) Upaya yang dilakukan oleh waria agar diterima di lingkungan masyarakat yaitu; 1) berusaha menjelaskan kepada masyarakt menjadi seorang waria bukanlah semata ingin menyimpang dari kodrat Tuhan, akan tetapi, ada hal yang sulit dipahai secara psikis, sehingga lebih dominan hasrat feminimnya. 5) melibatkan diri dalam berbagai kegiatan kemasyarakatan, profesional dibidang pekerjaan yang digelutinya, dan membagun komunikasi yang baik dengan masyarakat.

\section{PENDAHULUAN}

Undang-Undang nomor 39 tahun 1999 tentang HAM, di pasal 1 ayat 3 berbunyi "Diskriminasi adalah setiap pembatasan, atau pengucilan yang langsung maupun tidak langsung didasarkan pada perbedaan manusia atas dasar agama, suku, ras, etnis, kelompok, golongan, status sosial, status ekonomi, jenis kelamin, bahasa, keyakinan politik. Berdampak pada pengurangan, penyimpangan, atau penghapusan pengakuan, pelaksanaan atau pengakuan hak asasi manusia dan kebebasan dasar dalam kehidupan baik individual maupun kolektif dalam bidang politik, ekonomi, hukum, sosial, budaya, dan aspek kehidupan lainnya.

Berdasarkan penafsiran dari komunitas pendukung waria sebagai gender baru, bila ditinjau dari hukum positif komunitas Waria berada di bawah payung hukum Hak Asasi Manusia, oleh karena itu meminta masyarakat dan negara untuk mengakui keberadaan komunitas ini, bila kita melihat dari konstitusi Indonesia yakni UUD 1945 Pasal J yang menyatakan; 1) Setiap orang wajib menghormati hak asasi manusia orang lain dalam tertib kehidupan bermasyarakat, berbangsa, dan bernegara; 2) Dalam menjalankan hak dan kebebasannya, setiap orang wajib tunduk kepada pembatasan yang di 
tetapkan dengan undang-undang dengan maksud semata-mata untuk menjamin pengakuan serta penghormatan atas hak dan kebebasan orang lain dan untuk memenuhi tuntutan yang adil sesuai dengan pertimbangan moral, nilai-nilai agama, keamanan, dan ketertiban dalam suatu masyarakat demokrasi.

Menurut data Direktorat Jenderal Administrasi dan Kependudukan Departemen Dalam Negeri, jumlah waria di Indonesia tahun 2005 silam, mencapai 400.000 jiwa. Jumlah ini masih berupa fenomena gunung es, karena masih banyak waria yang belum masuk dalam hitungan, dan disinyalir angka ini akan terus bertambah setiap tahunnya.n Sebagai individu maupun bagian dari kelompok sosial, waria berusaha untuk mendapat bagian dalam berbagai ruang social. Berbagai cara dilakukan untuk mendapat pengakuan, sehingga munculnya penyelenggaraan kontes Miss waria, baik di tingkat regional maupun nasional dan munculnya berbagai figur waria ke permukaan publik, sebagai figur waria, untuk mastikan langkah awal agar diterima di masyarakat.

Waria merupakan akronim dari "wanita pria". Perilaku menyimpang ini disebut sebagai kelompok transgender dan sempat menjadi perbincangan hangat public di tahun 2017, ditandai dengan munculnya aktivis dan komunitas yang memperjuangkan waria sebagai gender baru baik secara konstitusional maupun secara sosial kemasyarakatan. Sedangkan disisi lain hal itu sangat tidak wajar, karena melanggar kodrat Tuhan.

Pola hidup waria termasuk kedalam perilaku menyimpang atau deviasi sosial. Perilaku menyimpang merupakan segala bentuk tutur kata atau perbuatan yang tidak sesuai dengan nilai dan norma sosial dalam masyarakat. Segala hal yang bertentangan dengan peraturan, dianggap sebagai perilaku menyimpang. Nakmun sebagai manusia yang bijak, perlu pahami dari berbagai sudut pandang mengapa lelaki secara fisik normal tapi memilih menjadi waria, mungkin bisa oleh berbagai faktor, seperti; ekonomis, biologis, psikologis dan kebudayaan sosial.

Ditinjau dari faktor ekonomis masalah sosial disebabkan oleh ketidakmampuan seseorang dalam memenuhi kebutuhan hidup sendiri maupun keluarganya secara layak. Masalah sosial yang disebabkan oleh faktor budaya menunjukan adanya pertentangan nilai, norma, dan kepentingan sosial akibat adanya proses perubahan sosial dan pola masyarakat heterogen/multikultural. Sedangkan masalah sosial disebabkan oleh faktor biologis dan ketidakstabilan kondisi biologis atau pengaruh gen bawaan. Masalah sosial yang disebabkan oleh faktor sosial biasanya terjadi akibat nilai dan norma tidak diakomodasi dengn baik dalam setiap perilaku individu.

Nilai sosial merupakan standar atau kualitas yang berharga dan diinginkan oleh orang atau masyarakat yang memegangnya. Nilai merupakan kumpulan sikap dan perasaan yang diwujudkan melalui perilaku sosial yang dianggap baik dan bersifat abstrak. Berdasarkan ciri-cirinya nilai terbagi atas nilai dominan, nilai instrumental dan nilai yang mendarah daging. Sedangkan norma adalah petunjuk atau patokan perilaku yang pantas dan dibenarkan dalam menjalani interaksi sosial di suatu masyarakat tertentu. Pelanggaran terhadap norma sosial akan dikenai sanksi. Norma merupakan bentuk konkrit/nyata dari nilai sosial yang ada dalam masyarakat. Jenis-jenis norma sosial yaitu cara (usage), kebiasaan (folkways), tata kelakuan (mores), adat istiadat (customs), dan hukum (laws). Apabila, nilai yang dimaksud diatas dilanggar atau menyimpang maka, akan dikenakan sanksi sosial dari masyarakat bagi mereka yang melanggarnya (Kartono, 2001).

Eksistensi para kaum waria di tengah masyarakat kita bukan merupakan hal yang baru lagi meski tidak implisit ke dalam identitas gender normatif yaitu gender laki-laki dan perempuan (Alfaris, M. R., 2018). Kelompok Waria dalam lingkungan sosial merupakan kelompok minoritas yang dituntut berperilaku seperti masyarakat mayoritas (heteroseksual). Orientasi seksual, identitas seksual \& gender serta ekspresi gender "haras" berada dalam satu garis lurus sesuai dengan jenis kelamin yang dimiliki, maka akan terjadi stigma seperti abnormal, pendosa, sakit, belok (Indiana Laazulva, 2013). 
Kaum waria telah mengkonsep dirinya, sebgai perempuan secara sadar atas keputusannya sendiri. Dari kategori kemampuannya mereka memahami betul seperti apa kemampuan seorang wanita, kemudian perasaan mereka pun juga ikut masuk ke dalam jiwanya, di mana perasaan lembut atau lainnya yang dimiliki oleh perempuan itu terintegrasi pada diri para waria tersebut. Setelah fasefase tersebut di jalani, maka fase berikutnya menuju kepada kondisi fisik, dalam hal ini kondisi fisik para waria juga sudah jelas sangat melekat karena untuk melengkapi karakteristik perempuan dalam fisik laki-laki.

Pola hidup waria, secara psikis yang dialami sangat memprihatinkan dan terpaksa dilakukan demi keberlangsungan hidupnya. Di samping itu krisis identitas mereka tidak hanya sebatas dari psikologi mereka saja melainkan dalam perilaku sosial mereka juga. Hal tersebut dapat menimbulkan banyak hambatan social guna mengaktualisasikan hubungan sosial pada umumnya atau bahkan hubungan sosial yang lebih luas lagi. Kesulitan mereka adalah dalam mengintegrasikan dirinya ke dalam struktur sosial masyarakat. Secara garis besarnya (Koeswinarno, 2004).

Menurut Giddens (1989) bahwa konsep gender menyangkut "The Psychological, social and cultural differences between males and females", yakni perbedaan psikologis, sosial, dan budaya antara laki-laki dan perempuan. Dalam artian, Giddens menekankan bahwa adanya perbedaan atas gender dari sisi psikologi, sosial, dan budaya karena sifatnya yang situasional. Sedangkan Lasswell (1987) mengatakan bahwa gender terletak pada pengetahuan dan kesadaran, baik secara sadar ataupun tidak bahwa diri seseorang tergolong dalam suatu jenis kelamin tertentu dan bukan dalam jenis kelamin lain.

Robert Brannon (1996) menelaah konsep peran dalam kehidupan social, sebagai bagian dari dari drama yang sedang diperankan oleh seseorang. Oleh karenanya, peran gender laki-laki atau peran gender perempuan adalah seperti sebuah script atau naskah dimana laki-laki serta perempuan yang ikut memenuhi bagian yang tepat dalam bertindak maskulin atau feminine. Jadi peran gender adalah serangkaian kegiatan sosial yang signifikan terkait dengan laki-laki atau perempuan.

Hurlock (1990) menjelaskan konsep diri adalah gambaran yang dimiliki orang tentang dirinya. Konsep diri ini merupakan gabungan dari keyakinan yang dimiliki individu tentang mereka sendiri yang meliputi karakteristik fisik, psikologis, sosial, emosional, aspirasi dan prestasi. Kemudian Stuart \& Sudeen (1998), konsep diri adalah semua ide, pikiran, kepercayaan dan pendirian yang diketahui individu tentang dirinya dan mempengaruhi individu dalam berhubungan dengan orang lain. Terlepas dari cara sesorang memahami konsep diri, pola hidup waria selalu identik dengan berbagai prostitusi, diantaranya pergaulan bebas, miras, homo seksual dan masih banyak penyimpangan lainnya yang belum bisa disebutkan secara rinci. Termasuk dalam penyebaran penyakit HIV.

Mencermati berbagai pandangan dan pendapat masyarakat terhadap waria, melatarbelakangi peneliti, untuk melakukan penelitian tentang pola hidup waria di Desa Timu Kecamatan Bolo, Kabupaten Bima”. Hal tersebut menarik untuk diungkap sebagai fenomena penyimpangan sosial di masyarakat. Adapun tujuan dari penelitian ini yaitu; 1) mendeskripsikan berbagai tanggapan masyarakat terhadap pola hidup waria; 2) mengidentifikasi berbagai upaya yang dilakukan oleh waria agar diterima dilingkungan masyarakat.

\section{METODE PENELITIAN}

\section{Jenis dan Desain Penelitian}

Penelitian ini menggunakan metode kualitatif deskriptif. Data yang dihasilkan berua informasi yang diuraikan dalam bentuk kata-kata. Menurut Sugiyono (2006:15) bahwa metode penelitian kualitatif adalah metode penelitian yang berdasarkan pada filsafat post Positivisme, digunakan untuk meneliti pada kondisi obyek yang alamiah, dan peneliti sebagai instumen kunci (key instrument). 


\section{Teknik Cuplikan/Sampling}

Teknik sampling dalm penelitian ini, menggunakan subjek penelitian yang diambil secara purposive, yaitu terdiri dari 10 waria, sebagi informan kunci, 10 oarng perwakilan dari pemerintah dan dinas terkait dan masyarakat sebagai informan Pembanding.

\section{Teknik Pengumpulan Data}

Teknik pengumpulan data dilakukan dengan 3 cara yaitu;

1) Observasi diartikan sebagai pengamatan dan pencatatan secara sistematik terhadap gejala yang tampak pada objek penelitian

2) Wawancara atau percakapan dengan maksud tertentu. Percakapan itu dilakukan oleh dua pihak, yaitu pewawancara yang mengajukan pertanyaan dan yang diwawancarai yang memberikan jawaban atas pertanyaan

3) dokumentasi dalam mengumpulkan data melalui peninggalan tertulis, seperti arsip-arsip dan termasuk juga buku-buku tentang pendapat, teori, dalil atau hukum-hukum

\section{Teknik Analisis Data}

Metode pengolahan data atau teknik analisa data dalam penelitian ini dilakukan secara terus menerus sejak awal sampai akhir penelitian. Analisa data dalam penelitian ini menggunakan teknik deskriptif yang ditekankan pada analisa kualitatif dengan teknik induksi dan deduksi, tidak menutup kemungkinan juga argumentasi

\section{HASIL DAN PEMBAHASAN}

\section{Pandangan masyarakat tentag pola hidup waria}

Waria merupakan pria yang berpenampilan seperti layaknya seorang perempuan dengan kata laian wanita pria. Mereka tidak memiliki alat kelamin seperti wanita hanya saja, mereka merasa hasratnya seperti seorang perempuan. Sehingga prilaku yang mereka tunjukan, bagi masyarakat pada umumnya itu di anggap sebagai suatu hal yang tidak lazim, dan menurut agama suatu hal yang menyimpang dari norma maupun koridor yang berlaku di masyarakat (Sahit Prasetio, 2010). Kehidupan waria sebenarnya termasuk kedalam perilaku menyimpang. Perilaku menyimpang sering disebut deviasi sosial. Perilaku menyimpang merupakan segala bentuk tutur kata atau perbuatan yang tidak sesuai dengan nilai dan norma sosial dalam masyarakat. Segala hal yang bertentangan dengan peraturan akan dianggap sebagai perilaku menyimpang (Nadia, 2005).

Masyarakat, sebagai sebuah kumpulan individu memiliki sejumlah norma dan nilai sosial di dalamnya yang tujuannya untuk menata keteraturan dalam masyarakat itu. Norma dan nilai sosial itu diperoleh bukannya tanpa proses, melainkan lewat proses pengintegrasian berbagai macam kepentingan dan perbedaan antar individu dengan pedoman agama atau kepercayaan yang berlaku dalam masyarakat tersebut. Ketika nilai-nilai dan norma dalam masyarakat yang telah disepakati bersama itu dilanggar, maka akan terjadi suatu kondisi yang tidak teratur dalam masyarakat tersebut dan hal ini akan menyebabkan adanya disintegrasi masyarakat (Koeswinarno, 2004).

Misalnya kemunculan seorang waria yang merupakan sebuah fenomena sosial tersendiri bagi masyarakat kita dimana sampai saat ini waria adalah salah satu kaum yang terpinggirkan, bahkan menjadi kaum yang paling terpinggirkan. Banyak orang yang memandang sebelah mata terhadap eksistensi waria, bahkan secara terang-terangan mereka beranggapan negatif, seperti anggapan bahwa waria adalah sampah masyarakat, waria sebagai penyebar penyakit masyarakat, dan kesemuanya itu seolah menyiratkan bahwa waria selama ini diperlakukan sebagai sebuah objek, bukan subjek. Sehingga waria sering mendapat perlakuan yang semena-mena, dihina, dan dicaci. 
Jika dilihat secara fisik, waria merupakan salah satu bagian dari penyuka sesama jenis (homoseksual). Namun demikian ada suatu hal yang membatasi secara jelas antara kaum homoseks dan kaum waria. Sebagai contohnya adalah pada penampilan pada pakaian. Homoseks tidak merasa perlu berpenampilan dengan memakai pakaian perempuan, sebaliknya seorang waria merasa dirinya adalah perempuan sehingga ia harus berpenampilan halus sebagaimana perempuan.

Masyarakat, dalam mereka memaknai waria tidak terlepas dari ruang-ruang yang dipakai oleh waria itu untuk beraktivitas, khususnya dalam konteks ruang secara publik dimana identitas seseorang ter-representasikan melalui ruang publik tersebut sehingga masyarakat bisa mengetahui identitas seseorang dengan melihat perilakunya dalam ruang publik. Selain ruang publik, ruang yang dipakai waria untuk beraktivitas secara sosial adalah dalam keluarga.

Kemunculan waria dalam masyarakat, pastilah bermula dari keberadaannya dalam keluarga karena keluarga adalah ruang pertama kali manusia hidup secara sosial dan tempat dimana pertama kali seseorang mendapat pelajaran mengenai kepribadian lewat proses-proses sosialisasi. Konteks budaya mendapat perhatian tersendiri dalam kemunculan waria. Proses-proses ketika masih kanakkanak, kemudian ketika dibesarkan dalam lingkungan keluarga lalu mendapatkan sebuah kesadaran akan kodrat dirinya pada masa remaja menjadi faktor yang berperan penting dalam proses seseorang menjadi waria.

Bentuk-bentuk tekanan sosial seperti yang disebutkan di atas seringkali didapatkan oleh waria. Sebagai contoh, waria yang menjajakan dirinya sebagai pekerja seks komersial saat sedang nongkrong di pinggir jalan. Kadang ada orang yang menghina keberadaan mereka dengan cara bersiul misalnya, atau dengan penggodaan baik secara verbal melalui kata-kata yang kurang enak didengar maupun dengan tindakan-tindakan seperti mencolek. Contoh lain, pada waria yang mencari uang dengan mengamen di lampu merah. Meskipun hanya dengan gerak bibir yang menyiratkan ekspresi jijik, menyepelekan, dan bahkan merendahkan, bagi waria hal itu merupakan hal yang sensitif. Kekerasan yang mereka alami lebih banyak berupa kekerasan simbolik.

Brbagai tekanan sosial yang dialami oleh waria dalam masyarakat lebih berat daripada tekanan yang mereka alami dalam keluarga. Hal ini berkaitan dengan kehidupan bermasayarakat yang selalu terdapat konsensus-konsensus yang harus dipatuhi sedangkan konsensus itu seringkali tidak memihak pada waria, namun malah menjadi alat untuk melegalkan masyarakat mencemooh dan melecehkan waria secara semena-mena dan seenaknya sendiri.

Waria yang ada di linkungan masyarakat Desa Timu dianggap sebagai prilaku yang menyimpang dari agama dan nilai-nilai sosial, waria lebih cenderung menjerumuskan diri pada pergaulan bebas seperti, pesta miras, narkoba, penyimpangan seksual dan lain sebagainya, ada juga yang mengatakan bahwa menjadi waria bukanlah sepenuhnya kemauan mereka akan tetapi bawaan sejak lahir (factor biogenetic), sehingga mudah terpengaruh oleh lingkungan tempat mereka berada. Seyogyanya masyarakat menolak waria sebagai bagian dari masarakat, karena sangat menjijikan bagi sebagian orang dengan melihat berbagai prilaku yang di tunjukan oleh para waria, namun ada juga yang merasa sangat terhibur dengan keberadaan mereka karena dinilai sebagai sisi kehidupan yang unik dan menarik. Waria, berprilaku yang tidak lazim bagi masayarakat misalya, berpenampilan layakya perempuan, bernyani, bermain voli ball, percaya diri tingkat tinggi dan idealis). kehidupan para waria merupakan keragaman dari aspek social yang patut kita hargai dari sisi sesama manusia dan juga menghargai hak asasi seseorang untuk menetukan jalan hidupnya.

\section{Uapaya yang dilakukan waria untuk mendapatkan ruang dalam kehidupan social masarakat}

Penyesuaian diri dapat diartikan mengubah diri sesuai dengan keadaan lingkungan dan mengubah lingkungan sesuai dengan lingkungan sendiri. Setiap perubahan dalam kehidupan individu menyebabkan individu selalu berusaha untuk menyesuaikan diri dengan lingkungan (Ahmadi, 1991). 
Perjalanan hidup waria diawali dengan masa kecil yang berbeda dari kebanyakan orang, menyukai permainan perempuan, memilih bermain dengan teman perempuan dan memiliki kecenderungan berperilaku seperti perempuan. Semua itu terjadi dengan sendirinya tanpa dibuat-buat atau dipaksakan oleh siapapun. Subjek pun cukup mendapatkan perhatian dan kasih sayang dari orang tua mereka, dan mereka merasa tidak ada yang salah dengan pola asuh orang tua mereka. Subjek tidak setuju jika dikatakan bahwa kondisi mereka terjadi karena pola asuh orang tua dan pengaruh lingkungan, karena menurut mereka tidak ada yang salah dengan kedua hal tersebut.

Hinaan sudah diterima sejak kecil, dan di sekolah pun selalu menjadi bahan tertawaan temantemannya. Akan tetapi hal ini tidak mengurangi apa yang mereka rasakan ataupun mengurangi keinginan untuk bertingkahlaku seperti perempuan. Pada usia kanak-kanak mereka juga sudah memiliki ketertarikan pada sesama jenis, mulai dari sekedar rasa suka sampai dengan keinginan untuk memiliki dan menjalin hubungan lebih jauh. Tidak seperti laki-laki pada umumnya, pada saat mereka mengalami mimpi basah, mereka berfantasi/memimpikan berhubungan dengan sesama laki-laki

Waria sebagai bagian dari masarakat Indonesia dalam konteks keragaman, pada satu sisi hendaknya dapat di tempatkan sebagai sebuah kenyataan social yang tidak terelakan keberadaanya. Pada sisi lain bagi sebagian masyarakat Indonesia sebagai bentuk penyimpangan prilaku (devianbehavior) menurut kacamata masyarakat yang menggunakan ukuran normal dan tidak normal serta lazim dan tidak lazim dan ukuran-ukuran sejenis lainya (Hidayanto, 2010)

Kedua pandangan dan kondisi masyarakat dalam menyikapi keberadaan waria idealnya tidak selalu dihadapkan secara berhadapan (diametral) yang dikhawatirkan dapat menimbulkan dampak yang kurang mendukung bagi persatuan bangsa, dan pembangunan manusia Indonesia seutuhnya. Pembangunan manusia seutuhnya salah satunya dipahami sebagai upaya untuk menjunjung tinggi harkat dan martabat manusia Indonesia itu sendiri termasuk di dalamnya para waria. Dalam situasi dan kondisi seperti ini, kedewasaan sebagai bangsa akan teruji dalam mensikapi keberadaan waria (Sahit Prasetyo, 2010)

Idealnya, memahami waria hendaknya dipahami secara utuh (holistik), baik sebagai individu maupun anggota masyarakat yang memiliki kelebihan dan berbagai kekurangan. waria sebagai individu maupun bagian dari masyarakat, didalamnya terdapat potensi-potensi yang memungkinkan dikembangkan kearah yang lebih membangun atau konstruktif bagi upaya untuk memberdayakan waria dalam pembangunan bangsa. Disamping itu, pada sebagian waria juga terdapat keterbatasanketerbatasan sosialnya, misalnya gangguan dalam beradaptasi dengan lingkunganya, mempertahankan hidup dengan cara yang menyimpang seperti melacurkan diri, mengamen dan menggelandang di jalanan dan sebagainya (Hidayanto, 2010)

Pola hidup waria disebabkan oleh beberapa factor baik dari dalam diri sendiri (bawaan sejak lahir), maupun datangnya dari luar. Beragam permasalahan yang di alami oleh para waria menjadikan proses terbentuk pola pikir diri mereka berbeda, sehingga ada kalanya waria tersebut ingin kembali normal akan tetapi sudah tidak bisa lagi degan alas an hasrat byang ada dalam dri mereka yang sulit dijelaskan secara logika.

Berbagai keahlian yang mereka miliki, merupakan bentuk keunikan yang mereka miliki sebagai mahluk ciptaan tuhan, namun tidak semua orang bisa menjadi seperti mereka, dalam bidang pekerjaan para waria selalu professional dan ingin menunjukan yang terbaik kepada masyarakat supaya penilaian yang selama ini menyudutkan para waria pada posisi yang tidak bermoral supaya bisa dinetralisir melalui sikap dan bentuk tanggung jawab pada profesinya, dan tak jarang juga waria memiliki jiwa sosial yang slalu ingin saling membantu satu sama lainnya.

Berbagai upaya yang mereka lakukan supaya di terima di masyarakat sebagai gender baru bahkan mereka rela melakukan apa saja demi mendapatkan hubungan baik dengan para masyarakat supaya 
menghargai keberadaan mereka sebagai bagian dari kelompok masarakat, tampa memandang rendah mereka dan tidak selamanya mereka para waria menebar aura negatif yang akan merusak moral generasi.upaya demi upaya yang di lakukan waria tentu akan menentukan sikap masyarakat kepada mereka.

\section{KESIMPULAN}

Berdasarkan hasil penelitian yang dilakukan bahwa; 1) tanggapan masyarakat terhadap pola hidup waria yaitu; a) waria dinilai oleh masyarakat pada umumnya sebagai prilaku menyimpang, melanggar kodrat tuhan dan norma agama; 2) menimbulkan keresahan dan kekhawatiran para orangtua, karena hawatir anak-anaknya terjerumus dalam pola pergaulan waria; c) sebahagian kecil masyarakat menggap bahwa waria sebagai dinamika kehidupan bermasyarakat yang biasa-biasa saja.; 2) Upaya yang dilakukan oleh waria agar diterima di lingkungan masyarakat yaitu; 1) berusaha menjelaskan kepada masyarakt menjadi seorang waria bukanlah semata ingin menyimpang dari kodrat Tuhan, akan tetapi, ada hal yang sulit dipahai secara psikis, sehingga lebih dominan hasrat feminimnya. 5) melibatkan diri dalam berbagai kegiatan kemasyarakatan, profesional dibidang pekerjaan yang digelutinya, dan membagun komunikasi yang baik dengan masyarakat.

\section{Daftar Pustaka}

Alfaris, M. R. (2018). Eksistensi Diri Waria Dalam Kehidupan Sosial Di Tengah Masyarakat Kota (Fenomenologi Tentang Eksistensi Diri Waria Urbanisasi di Kota Malang). Widya Yuridika: Jurnal Hukum, 1(1).

Hafidz. 2005. Mengapa Harus Jadi Waria?. Artikel diakses pada tanggal 12 November 2011 di situs http://www.dudung.net/buletin-gaulislam/ mengapa-harus-jadi-waria.html

Hartono ddk. 2004. Interaksi sosial. Jakarta: Erlangga.

Hidayanto. 2010. Latar Belakang Kehidupan Laki-Laki yang Menjadi Waria. Skripsi Fakultas Psikologi. Tidak diterbitkan. Universitas Surabaya.

Indiana Laazulva, 2013 Menguat Stikma Kekerasan dan Diskriminasi pada LGBT di Indonesia,(Jakarta Selatan: Arus Pelangi

Kartodirdjo. 1992. Pendekatan ilmu sosial. Jakarta: Gramedia.

Kartono. 2001. Penerapan nilai sosial dan budaya. Jakarta: Gramedia

Koeswinarno. 2004. Hidup sebagai waria. Yogyakarta: PT LKIS Pelangi Angkasa.

-Konsep Diri dan Latar Belakang Kehidupan Waria (Studi Kasus terhadap Waria di Kota Semarang Tahun 2007). Skripsi Jurusan Psikologi Fakultas Ilmu Pendidikan. Universitas Negeri Semarang: Semarang.

Lolita, Tya. 2010. Pranata sosial kehudupan waria. Atikel sosiologi. Universitas Gadjah Mada Yogyakarta

Miller K. 2010. Communication Theories: Perspectives, Processes, and Contexts

Moleong. 2002. Metodelogi Penelitian Kualitatif. Bandung: PT Remaja Rosdakarya

Nadia. 2005. Relasi Interpersonal Waria (Studi Kasus terhadap Waria F di Cimahi). Skripsi Jurusan Psikologi Fakultas Ilmu Pendidikan.Universitas Pendidikan Indonesia.

Paul H., 1999. Sosiologi. Edisi ke VI jilid I: Erlangga.

Polama. 2010. Ethnik dan budaya masarakat. Surabaya: PT Laskar indah. 
Prasetyo, Sahit. 2010. Waria dalam pandangan sosial dan agama. Skripsi ilmu sosial. STKIP Hamjan Wadi: Lombok timur

Priadi. 2012. Memahami istilah perspektif. Jakarta: Erlangga.

Rachman. 1994. Prosedur Penyelenggaraan Penelitian Kualitatif (Handout Mata Kuliah Metode Penelitian Kualitatif. Surabaya: UNTAG.

Sairin. 2002. Kegiatan Ekonomi Masyarakat. Jakarta: Fakultas Ekonomi Universitas Indonesia

Studea. (2006). Latar Belakang Kehidupan Laki-Laki yang Menjadi Wria: Sebuah Kegagalan dalam Proses Pendidikan Pembentukan Identitas Gender. Artikel Psikologi Universitas Tarumanegara. Artikel diakses pada tanggal 16 Juni 2011 di situs www.psikologi.tarumanagara.ac.id

Sugiyono. 2006. Dasar-dasar penelitian kualitatif. Jakarta: Erlangga.

Suharsimi Arikunto. 2006. Metode penelitia kualitatif. Jakarta: Erlangga

Sujatmiko. 2005. Intervensi Kelompok pada waria Remaja yang Mengalami Reaksi Stress Pasca Trauma Akibat Kekerasan Personal. Artikel diakses pada tanggal 28 Desember 2011 di situs http://pelangiwarasjiwo.wordpress.com/2011/04/18/p/ 